International Journal of Application Computer Science and Informatic Engineering (ACSIE)

Vol.1, No.2, November 2019, pp. 65 74

ISSN (online): $2685-4600$

\title{
Design and Development Key Board For Aksara Bali On Android With Auto Parts Improvement
}

\author{
Ida Bagus Ary Indra Iswara*1, Putu Praba Santika ${ }^{2}$, I Nyoman Saputra Wahyu Wijaya ${ }^{3}$ \\ ${ }^{1,2}$ Teknik Informatika,STMIK STIKOM Indonesia, Denpasar, Indonesia \\ ${ }^{3}$ Teknik Informatika, Universitas Pendidikan Ganesha, Bali, Indonesia \\ e-mail: *¹ Indraiswara@ stiki-indonesia.ac.id, ${ }^{2}$ Praba@ stiki-indonesia.ac.id, \\ ${ }^{3}$ Wahyu.wijaya@undiksha.ac.id
}

\begin{abstract}
Balinese is used as a natural language used in daily life in the islands of Bali, given the importance of preserving Balinese, the provincial government of Bali has tried to preserve Balinese in various ways, one of which is by issuing a Balinese Governor Regulation. Not only the government is trying to preserve Balinese language and script, some people are also trying to preserve it. The inclusion of Balinese script in Unicode makes it very easy to display Balinese script in various media. Balinese script is unique in the number of letters used. In this study, the device will be developed to enter in the form of a keyboard or keyboard and an application called Tamiang to facilitate users in typing and using the Balinese script on a computer device. The layout of the buttons on Tamiang are arranged according to the level of use of each character. Tamiang has only been developed on computer devices with multiplatform concepts. Along with technological developments, the computer device in this study will be developed Tamiang application on the Android platform. So that it can facilitate anyone in accessing and learning the Balinese language.
\end{abstract}

Keywords-Aksara Bali, key board, android, auto part improvement

\section{INTRODUCTION}

Humans need language to facilitate communication with each other. The various languages in the world, ranging from languages that are only used in a particular region, to languages that are agreed to be international languages have different characteristics. Technological developments contribute to facilitating limited communication due to distance and language differences in each region and country. In addition, communication is not only done by someone in one city, but it is also possible to communicate between people on different islands, or even between people in different parts of the world. This is what drives the determination of a language to be designated as a national language or an international language. The negative impact caused by the determination of a national or international language is language shift. Regional languages will be displaced and replaced with national languages and international languages.

Balinese is a regional language that is owned by the Balinese people. Book cultural extinction, states the Balinese language is one language that is experiencing a shift in usage [1]. The attitude of the speaker community who are not loyal to the local language. Language shift is a permanent change in the choice of a person's language for everyday needs, especially as a result of migration, or the occurrence of language changes, i.e. changes in communication over a period [2]. The shift in usage does not only occur in Balinese but also Balinese, Balinese is one of the archipelago's traditional scripts that developed in Bali.

The government is trying to preserve Balinese language and script, and some people are also trying to preserve it. One of them is I Made Suatjana submitted a proposal that Bali characters be included in Unicode or ISO 10646. Now Balinese characters are included in 
Unicode standards. The inclusion of Balinese script in Unicode makes it very easy to display Balinese script in various media. Balinese script is unique in the number of letters used [3], developed the input device in the form of a keyboard or keyboard and an application called Tamiang to facilitate users in typing and to use the Balinese script on a computer device. The layout of the buttons on Tamiang are arranged according to the level of use of each character. Tamiang is currently only being developed on computer devices with multiplatform concepts.

Along with technological developments, computer devices are slowly becoming obsolete, based on statistics from statcounter.com from April 2015 to April 2016, operating system users for computer devices are falling further behind. Users of the Windows operating system for Indonesia as much as $16.17 \%$, while users of the mobile operating system occupy the first position in Indonesia, which is around 50.68\%. The operating system is the Android operating system. Based on the description above, in this study a keyboard will be made that can be used for Android devices, considering that the Android operating system is the most operating system used in Indonesia. This keyboard can type Balinese script directly on an Android device. Aside from being a means of input, this keyboard will be implemented in the ability to automatically correct errors in writing rules (pairs of Balinese characters).

\section{METHODS}

This research is motivated by the analysis of the problems that have been done. Based on the problems that have been formulated, the objectives and benefits of this paper. The purpose of this research is to design and build an Android Balinese keyboard, so that Android users can type Balinese script. The results of this study are expected to help Android users to type Balinese script, thus increasing the use of Balinese script in their daily lives.

There are two main works carried out in the research carried out, namely the design and implementation of a virtual keyboard with the addition of the auto correct feature that uses the provisions of the Balinese script pairs in the rank of wianjana. Research conducted in this study are as follows:

1. Data Collection

The data collection step is a crucial step in the process and results of the research to be carried out. Errors in carrying out data collection in one study, will have a direct impact on the process and results of a study. Without field data, the process of data analysis and conclusion of research results cannot be carried out. Data collection methods used in this study are the method of observation, interviews, and literature study.

2. Analysis and Design

An application must certainly be supported by data as a source of information in conducting analysis. The results of the analysis are then used to design. The analysis conducted in this study is a layout that makes it easy for users and the auto correct algorithm based on the Balinese script pairs.

3. Implementation of the Virtual Keyboard application

After going through the design stage, which is designing Balinese script layout and grouping, the PaTik Bali keyboard application is implemented in the JAVA programming language using the Android Studio tool.

4. Testing

The final step in the research phase is testing. The testing conducted in this study is blackbox testing. This stage aims to check and ensure each function and feature contained in the system can run in accordance with the design. This stage includes system development that can be done in the future

\subsection{Related research}

Learning media about Balinese script has been packaged in forms applications that can be installed or installed on gadgets that use the Android operating system [4]. Research conducted focuses on learning media to recognize shapes, sounds, and writing. Learning options

ACSIE Vol. 1, No. 2, November 2019: $65-74$ 
will include several learning menus including basic Balinese script learning, learning Balinese numbers, and stringing words. This learning application uses games as a medium to package these things. The research has not yet discussed the rules of writing such as "pasang aksara" dan "pasang pageh".

Research conducted, discusses about a learning media about Balinese script specifically about "pasang pageh" [5]. The learning media is packaged in the form of educational games. The educational game "Pasang Pageh Aksara Bali" is implemented on the Android platform. This game was created using the Corona application which is based on Programming Languages Lua and by using the Drag and Drop Method. This educational game focuses on learning how to understand about the correct Pairs of the Balinese Script. Pairs of Page are a writing system for Balinese script. With the availability of this learning media, it is hoped that it can help academics to understand how the rules are in writing Balinese script.

One of the facilities that is often used to do word processing for writing using Balinese script is Bali Simbar. In 1996 Bali Simbar, a typing program for Balinese script with a computer was introduced to the public. There has been almost no improvement since then. In 2005 the Balinese script was proposed to be included in the UNICODE or ISO 10646 list. for Microsoft WINDOWS, so that the Balinese script can become a Smart Font, so that it can easily be used [6]. Bali Simbar still has shortcomings, Bali Simbar can only be used on Microsoft Word applications [7].

Tamiang Bali is a word processor application developed to make and edit files in Balinese script. The basic functions of a word processing application such as open, save, print and create new files, export files to PDF / JPG, copy, cut, paste and so on. The application is designed to be able to run on various operating systems, such as Windows, Linux, and MAC [3].

The word processing application for Balinese script that is available does not yet provide autocorret features for the script pairs. When there is a writing error or a rule is violated, the application is expected to provide an automatic fix. The author wants to develop the Tamiang Bali application that can run on the Android operating system.

\subsection{Research design}

The research will be carried out by implementing a virtual keyboard application on an android smartphone.

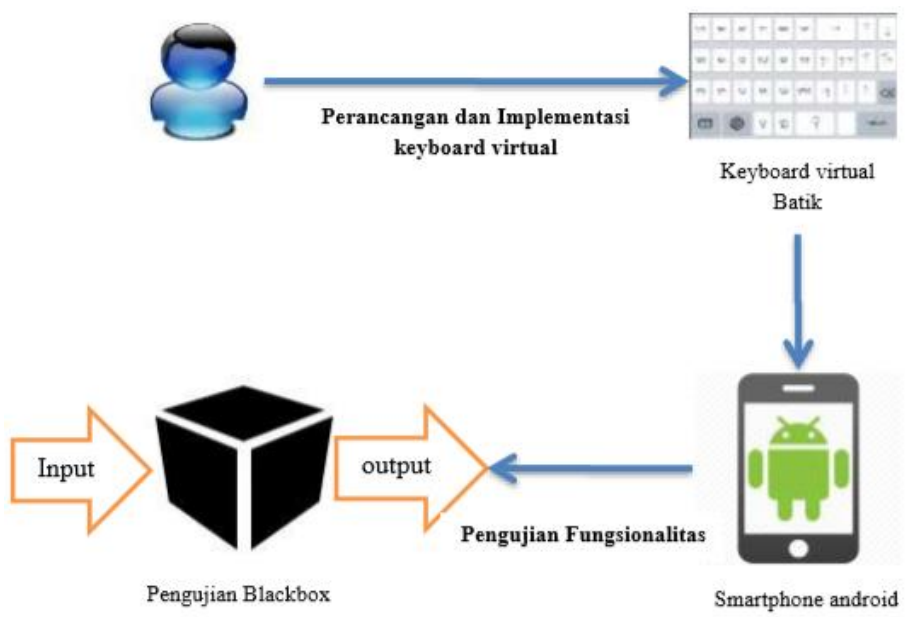

Figure 1. Research method

The Andorid Operating System used to implement virtual keyboards is limited in the Kitkat version. Figure 2 is a research design that will be carried out in research. Figure 1 shows that the study was planned through three main stages. The first virtual keyboard application was designed based on the layout and rules of writing Balinese script known as Bali script pairs. The 
planning is implemented with the JAVA programming language, so the resulting application can be applied to the Android operating system. In the second step, the keyboard application is installed on a smartphone. The smartphone used as part of the experiment is a smartphone with the brand name "Xiao Mi" with the type "Redmi Note 3". Testing will be performed on the virtual keyboard functionality using the black box testin method.

\subsection{Application Analysis}

Business After observing the research object, the keyboard, it was found that the Tamiang keyboard was still in the form of a physical keyboard used on a personal computer. The Tamiang keyboard does not yet have a virtual version that can be used or installed on a computer or Android device. The characters from Balinese script have a number that exceeds the number of keys available on the QWERTY keyboard layout so that in use requires the help of control keys ("ctrl") and "shift". Using the help of the "ctrl" and "shift" keys, each key on the QWERTY keyboard can hold two and at most three Balinese characters. Another problem that arises when using the Tamiang keyboard is when to use a combination of the "ctrl" and "sift" keys. There are some special rules for using some Balinese characters. Of course, ordinary users must learn the rules of the Tamiang keyboard to be able to use it. These conditions must be used as a reference in designing and implementing a virtual Balinese keyboard which will be called "PaTik Bali". There are two advantages of the "PaTik Bali" keyboard that will be built, and these advantages are the grouping of the Wianjana script, the self-literacy script, the sound alphabet, hangers and gameplan, as well as a collection of stewards. For grouping characters from each character, the group will be discussed further in point 2.3 about the layout design of the "PaTik Bali" keyboard. The second advantage is the feature to correct errors in writing the Balinese script called autocorrect. To be able to make corrections to typing errors due to errors of the writer, an algorithmic approach to the rules of Pairs of Balinese Script is needed.

\subsection{Keyboard Layout Design}

Keyboard Layout Design "PaTik Bali" keyboard layout design is designed by adopting the Tamiang keyboard layout concept. This is based on the Tamiang keyboard design that pays attention to the frequency of the emergence of Balinese script in a Balinese language article when viewed from the Latin characters used. Based on research conducted [3], the placement of the Balinese script is arranged into five layers. The concept of the layer can be seen in Figure 2.

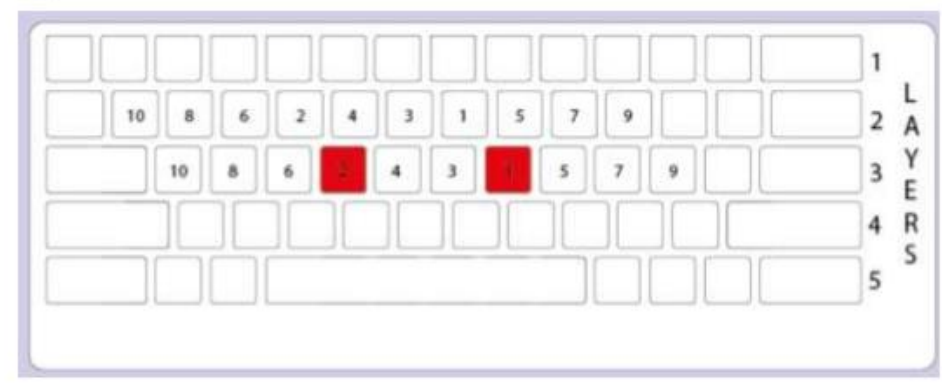

Figure 2 The Tamiang Keyboard Layer Concept [2]

Figure 2 shows the concept of layers on the Tamiang keyboard. The layout of the layers is adjusted according to the frequency of letters appearing in a Balinese language article. In the picture, the keyboard is divided into five layers, for the first layer representing numbers and punctuation, the second layer represents consonants other than the letters "s" and " $n "$. That is because the letters "s" and " $n$ " have the most frequency of occurrence for the letters that have the most appearances placed on layer 3. The following is a layout image from the "Tamiang Bali" keyboard.

ACSIE Vol. 1, No. 2, November 2019: $65-74$ 


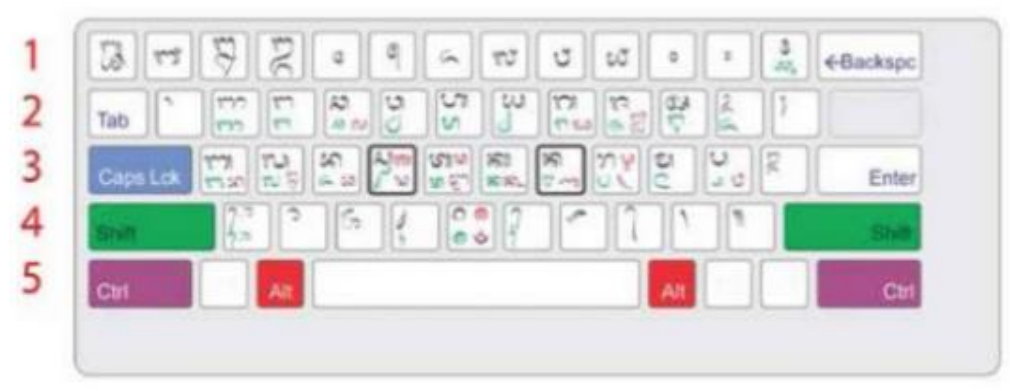

Figure 3 Balinese Tamiang keyboard [3]

Figure 3 shows the "Tamiang Bali" keyboard layout. Based on these images, it can be noted that the arrangement of the Balinese script is arranged according to the layout design shown in Figure 1. In Figure 2 it appears that each keyboard key contains more than one character. This is an effect caused by the Balinese script tides. In accordance with the statement stated [3], that in the rules of writing Balinese script. Each letter can be written in a different form, in accordance with the rules that apply to sentences written. However, a keyboard is limited to a maximum of only four keys in the shape of a character in the Balinese script.
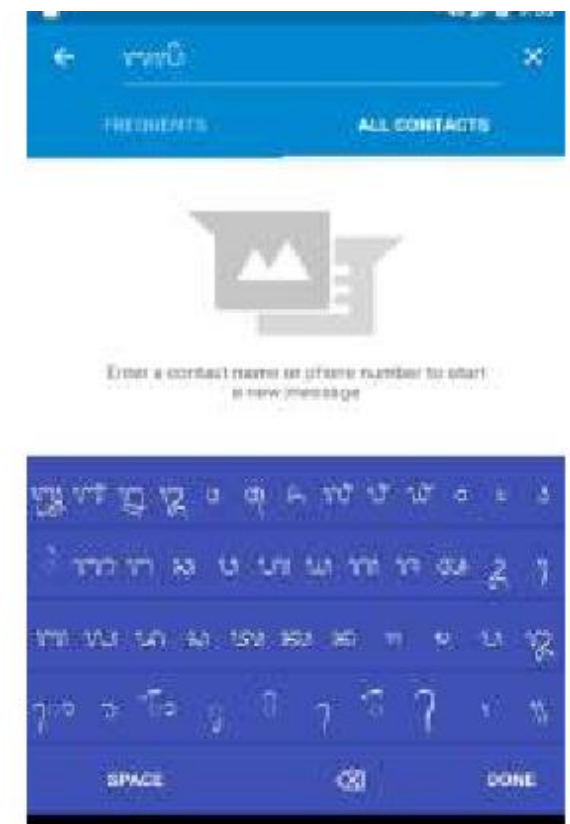

Figure 4 Bali PaTik Keyboard

The basic determination in the placement of characters in the Balinese script on the "PaTik Bali" keyboard that will be built refers to or adopts the concept used in "Tamiang Bali". In "Tamiang Bali", to use a different form of a letter character requires the help of the "shift, ctrl, and alt" keys. For "PaTik Bali", the concept adopted is limited to the placement of each character with other forms of the character. Meanwhile, to be able to choose other forms of a character does not require the help of the "shift, ctrl, and alt" keys, but instead uses the concept of a hold. The concept is used to facilitate users in choosing the shape of a Balinese character. For the keyboard "PaTik Bali" can be seen in Figure 4.

Figure 4 shows that the arrangement of the "PaTik Bali" keyboard is adjusted to the layout of the Balinese characters on the "Tamiang Bali" keyboard. 

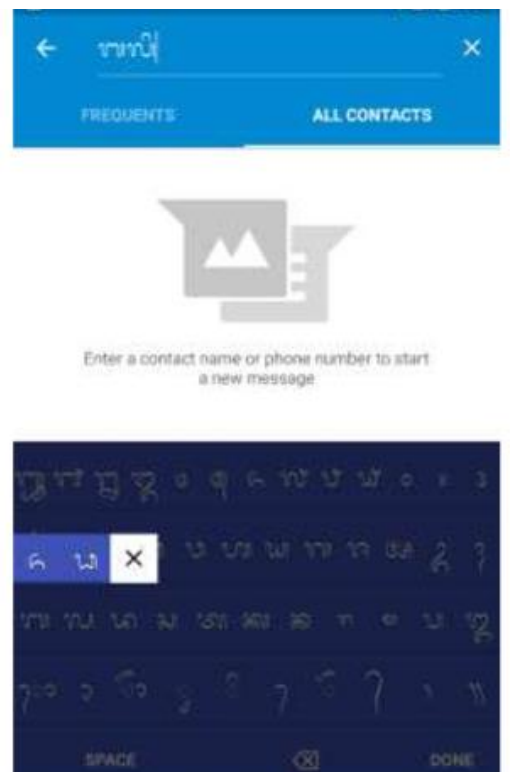

Figure 5 The results hold down the keys on the Bali PaTik Keyboard

The hold concept referred to in this keyboard is when on the "Tamiang" keyboard we have to press the "shift" or "ctrl" or "alt" key to use the "na propagation" character representing the "na" letter on the "PaTik Bali" keyboard. just hold down the "na" button for a period of 2 seconds. Then a pop-up option will appear for other variants of the letters "na" such as "ask" and "na propagation"[8][9]. This will certainly make it easier for users because they do not need to think about what keys to use when wanting other forms of certain letters, just simply holding the keys of certain letters on the keyboard. Pop up will give you a choice of several shapes of certain characters. To display the process of selecting different shapes in certain letters can be seen in Figure 5.

Figure 5 shows the results that occur when holding a letter key on the Bali PaTik keyboard. The example used is to hold the letter "da" in the Balinese script [10][11]. The result that occurs is that another form of the letter "da" appears, namely in the Balinese script called "da madu"[12]. "Da Madu" necessary when writing a word there is the letter $h$ after the letter "d" such as "dharma" which is one form of the rules of pairs of characters. Determination of the keyboard using the ASCII standard.

\subsection{Approach to Wianjana Script Alphabet Algorithm}

In writing Balinese script, we must pay attention to the rules called Balinese script pairs. Pairs of Balinese scripts have many rules which allow the writer to determine the wrong characters which must be used in writing Balinese. To anticipate the ignorance of lay writers, this study provides an additional feature, the "autocorrect" feature, which aims to correct incorrect writing typed by users of "PaTik Bali". This feature requires an algorithm or logic rule formed from Balinese script pairs. For the "autocorrect" feature in this study is still limited in the pairs of Wianjana characters. The following algorithm will be given to the pairs of scripts approach.

1. Start

2. Prepare autocorrect rules, which consist of several rules for writing the correct Balinese script according to pairs of Wianjana script

3. User input a letter or script.

4. Starting from the input of the two applications will check the comparison of the two characters entered with the saved rule. If the comparison of two characters is in the rule, then automatically one of the characters will be replaced with the correct one according to the rule.

5. End.

ACSIE Vol. 1, No. 2, November 2019: $65-74$ 


\section{RESULTS AND DISCUSSION}

\subsection{Based System Interface}

PaTik Bali application is built with Android Studio. In this application only uses an interface layer that can accommodate the entire character of Balinese script. The Bali PaTik interface can be shown in Figure 6.
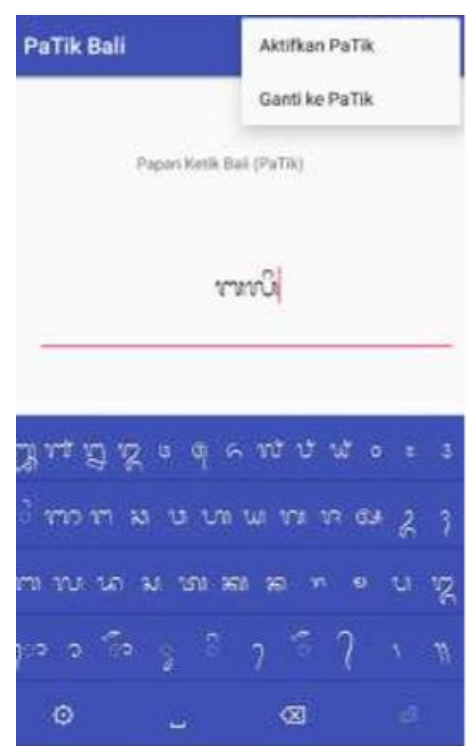

Figure 6 Interface of PaTik Bali

Figure 6 the application interface design is adjusted to the Tamiang Bali layout discussed earlier. To input each script is done by touching the screen in accordance with the given script. In addition there are pop ups that are used to select the same character but in different variants, for example when you want to choose the character "na rambat", the user needs to hold the screen that shows the "na biasa" character. This can be shown in Figure 7.

In figure 7 you will see several other variants of the selected character. It aims to facilitate the user in finding the desired character. Users no longer need to use additional keys such as ctrl and alt as implemented on the Tamiang Bali keyboard. Besides the goal is to minimize the layer used, it supports the previous reason that is making it easy for users to find the desired script. If more than one layer is used, the user may not know the location of the character in question, whether in the first layer or the next layer.

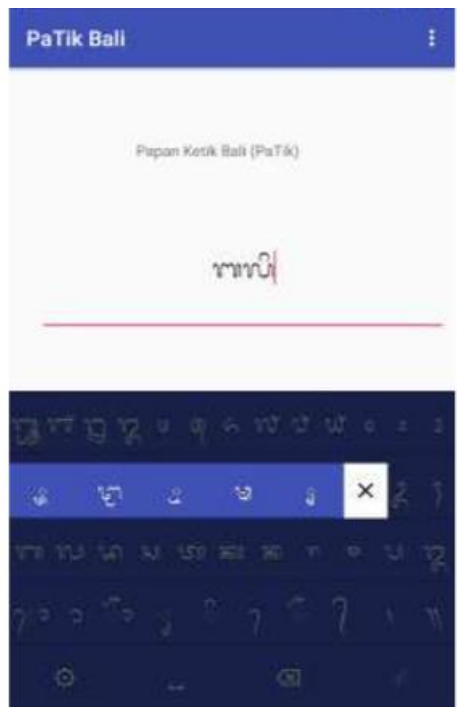

Figure 7 Pop Up Interface on PaTik Bali 
In addition to pop ups to see the hangers that are on PaTik Bali, this keyboard is equipped with features that make it easy for users. This feature is a setting button that is able to direct the user to choose another keyboard. Making this button makes it easier for users to move the keyboard position, because in the process of typing words on Android, maybe we will combine the Balinese script with Latin letters. This feature can be accessed from the button with the gear icon, once selected a pop up window will appear.

\subsection{Place the Wianjana Script on the Bali PaTik}

PaTik Bali was built (implemented) with Android Studio which has a JAVA programming language base. In Android Studio, to build a keyboard using two classes, namely main activity and PaTik class. Main activity is used to build keyboard interface templates. Whereas the PaTik class is used so that characters can be selected (onkey).

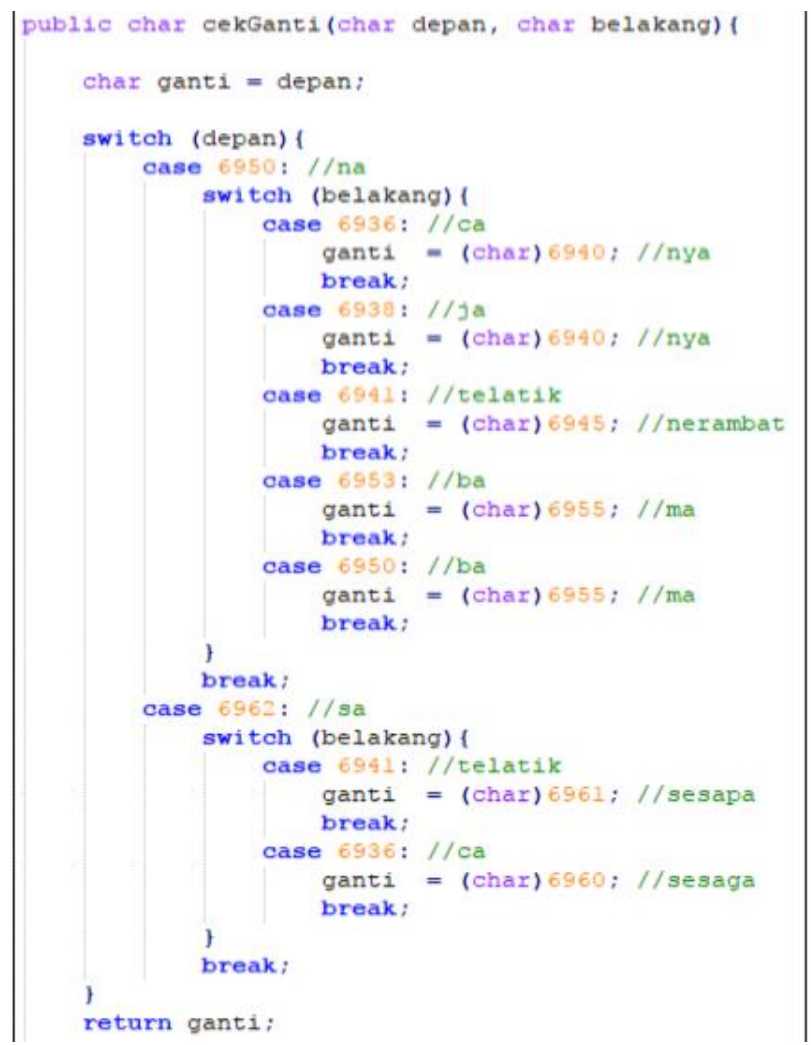

Figure 8 Code Method Replacement Character

The autocorrect feature provided at PaTik Bali adapts the rules of the wianjana script pairs discussed in Chapter IV. To implement the algorithm, the rules were made to compare the two Balinese characters. For the comparison code, the two characters are shown in Figure 6.5. The method used to determine two characters is shown in the public void onText code (new CharSequence Input). In this method the characters will be compared based on the location of the cursor. If in front of the cursor position there are no characters, the inputted characters will be directly displayed without checking the rules of the pairs of script pairs. If there are characters before the cursor, the characters at the front and back of the cursor will be matched to the Balinese script pairs. If you meet one of the rules, one of the characters will be replaced in accordance with the rules of the Wianjana script pairs.

Put the wianjana script in the Balinese script has several patterns. The pattern is outlined in the algorithm that has been explained in the previous discussion. In the implementation in JAVA the algorithm is poured with the switch case concept. The use of a switch case is determined based on the conditions taken into account. The switch case is more

ACSIE Vol. 1, No. 2, November 2019: $65-74$ 
appropriate than if then for the implementation of the wianjana script algorithm because the conditions to be considered in the script pairs algorithm are the comparisons of two successive characters.

One of the characters being compared will be changed according to the rules of the wianjana script pairs. In the rules of the Wianjana script pairs, there are several characters that are the determining values for the character changes. Seeing this problem, only one condition that is considered is to compare a condition, but it has many values that are seen, this is the advantage of the switch case concept compared to if then. The program code snippet used in this study can be seen in Figure 8.

The application of the wianjana script tides rules on the PaTik Bali keyboard shown in figure 8 uses a nested switch. The application of the CekGanti method considers three patterns. The first pattern is to replace the front character with the characters in the wianjana script pairs, as well as the second pattern, but what is replaced is the back character. Whereas the third pattern is slightly different, the third pattern is a rule that removes the two characters being compared and then replaces the deleted character with a new character

\subsection{Character Change Method}

The method for replacing the foreground character is required in most of the pairs of rules for scaffolding wianjana. In pairs of script characters, the rules for replacing characters are divided into two patterns, replacing a character or replacing both characters at once. this applies to the wianjana residents observed in the study, Talawia, Murdania and Osthia residents. Following in Table 1, a list of each wianjana character has a rule for changing characters.

Tabel 1 Rule of "Pasang Aksara Rangkep Wianjana"

\begin{tabular}{|c|c|c|c|c|c|}
\hline No & $\begin{array}{l}\text { Warga } \\
\text { Aksara }\end{array}$ & Huruf & Gantungan & Hasil & Contoh \\
\hline \multirow{4}{*}{1} & \multirow{4}{*}{ Talawia } & \multirow{2}{*}{ na } & $\mathrm{ca}$ & \multirow{2}{*}{$\begin{array}{l}\text { na menjadi na } \\
\text { rambat }\end{array}$} & 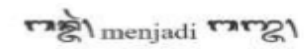 \\
\hline & & & ja & & uরీ menjadi uঙ્ર̂’ \\
\hline & & sa & ca & $\begin{array}{l}\text { sa menjandi sa } \\
\text { saga }\end{array}$ & 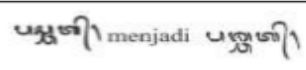 \\
\hline & & $\mathrm{da}$ & nya & da menjadi ja & 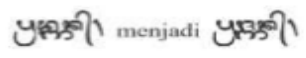 \\
\hline \multirow{4}{*}{2} & \multirow{4}{*}{$\begin{array}{l}\text { Murdan } \\
\text { ia }\end{array}$} & \multirow{2}{*}{ na } & tha latik & \multirow{2}{*}{$\begin{array}{l}\text { na menjadi na } \\
\text { rambat }\end{array}$} & xax)! menjadi \\
\hline & & & dha madu & & 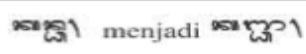 \\
\hline & & \multirow{2}{*}{ sa } & pha & \multirow{2}{*}{$\begin{array}{l}\text { sa menjadi sa } \\
\text { sapa }\end{array}$} & थु시 menjadi rgal \\
\hline & & & tha latik & & yaull menjadi ywu \\
\hline
\end{tabular}

\section{CONCLUSION}

Based on research that has been done, there are several conclusions obtained The design of PaTik Bali Application is carried out in various stages, namely: the stage of designing a virtual keyboard with android studio, designing an autocorrect algorithm, implementing Android Kitkat, and testing with Black Boxt testing. Based on testing the functionality of the black box, the autocorrect feature in accordance with the rules of the pairs of scripting scripts has been successfully implemented on the PaTik virtual keyboard.

Suggestions Based on the research conducted, several suggestions can be given for further research are additional features in the form of suggestions for sentences are given and Providing autocorrect features with overall rules for "pasang aksara bali" dan "Pasang Pageh". 


\section{REFERENCES}

[1] Wilian, Sudirman. 2005. "Bahasa Minoritas, Identitas Etnik, dan Kebertahanan Bahasa: Kasus Bahasa Sumbawa di Lombok.” Jurnal Masyarakat Linguistik Indonesia, Februari 2005, Tahun 23, Nomor 1. Jakarta: Masyarakat Linguistik Indonesia Bekerjasama dengan Yayasan Obor Indonesia.

[2] Kridalaksana, Harimurti. 1993. Kamus Linguistik. Jakarta: Gramedia Pustaka Utama.

[3] Pramarta, Cokorda Rai Adi and Dwidasmara, I B Gede. 2014. The Composition Approach Non-QWERTY Keyboard for Balinese Script. IEEE. Canada.

[4] Setiyawan, Putu Ary.2014. Balinese Alphabet Sebagai Aplikasi Media Pembelajaran Aksara Bali Berbasis Android Mobile Platform. Jurnal Merpati.

[5] Wirdiani, Ni Kadek Ayu dkk. 2015. Aplikasi Game Edukasi Pasang Pageh Aksara Bali Berbasis Android. Scientific Journal of Informatics.

[6] Anonim. 2009. Memakai Komputer Bali Simbar Dwijendra.

[7] Bagus, I Gusti Ngurah. 1980. Aksara Dalam Kebudayaan Bali;Suatu Kajian Antropologi. Denpasar : Universitas Udayana.

[8] Gubernur Bali, 2013. Peraturan Gubernur Bali Nomor 20 Tahun 2013 tentang bahasa, aksara dan sastra daerah Bali pada pendidikan dasar dan menengah. Bali.

[9] Medra, I Nangah. 2002. Pedoman Pasang Aksara Bali. Denpasar : Dinas Kebudayaan Propinsi Bali.

[10] Simpen, I Wayan. 2004. Pasang Aksara Bali. Denpasar : Upasa Sastra

[11] StatCounter.com, Top 8 Desktop, Mobile \& Tablet Operating System in Indonesia from april 2015 to april 2016 (http://gs.statcounter.com/\#desktop+mobile+tablet-os-IDmonthly201504-201604-bar) di akses tanggal 20 mei 2016

[12] Wiguna, I G.N.T, "Menelusuri Asal Mula Aksara Bali: Suatu Kajian Paleografi", Dalam Mutiara Warisan Budaya Sebuah Bunga Rampai Arkeologis Persembahan untuk Prof. Dr. I Gde Semadi Astra, hlm. hlm. 9-27. Denpasar, 2010.

ACSIE Vol. 1, No. 2, November 2019: $65-74$ 